Pesq. Vet. Bras. 36(11):1075-1080, novembro 2016 DOI: $10.1590 / \mathrm{S} 0100-736 \mathrm{X} 2016001100003$

\title{
Epidemiological, clinical and pathological aspects of an outbreak of periodontitis in sheep ${ }^{1}$
}

\author{
Natália S. Silva ${ }^{2 *}$, José A.S. Silveira ${ }^{3}$, Danillo Henrique S. Lima ${ }^{3}$, Henrique A. Bomjardim³, \\ Marilene F. Brito ${ }^{4}$, Ana Carolina Borsanelli5, Iveraldo S. Dutra6 and José D. Barbosa ${ }^{3}$
}

\begin{abstract}
Silva N.S., Silveira J.A.S., Lima D.H.S., Bomjardim H.A., Brito M.F., Borsanelli A.C., Dutra I.S. \& Barbosa J.D. 2016. Epidemiological, clinical and pathological aspects an outbreak of periodontitis in sheep. Pesquisa Veterinária Brasileira 36(11):1075-1080. Universidade Federal Rural da Amazônia, Campus Paragominas, Rodovia PA-256, Bairro Nova Conquista, Paragominas, PA 68627-451, Brazil. E-mail: natalia.silva@ufra.edu.br

The objective of this study was to describe the epidemiological, clinical and pathological aspects of an outbreak of periodontitis in sheep that occurred on a rural property in Benevides, in the state of Pará, Brazil. The first clinical signs of this disease in the herd visible nodular swollen mandible - were observed about one month after the sheep began grazing on a recently renovated Panicum maximum cv. Massai pasture; the animals were also supplemented with elephant grass (Pennisetum purpureum). From the 545 adult Santa Ines, Dorper, Texel and crossbred sheep, 20 (3.7\%) showed facial bulging, particularly of the mandible. These 20 sheep, which were generally over 36 months of age, had low body condition scores as well as dull and ruffled coats; many of them had loose or missing pre, upper or lower molars, showed the formation of abscesses and fistulas, exhibited pain upon palpation and had difficulty chewing. In the same herd, the prevalence of periodontal lesions at the premolars and molar teeth was evaluated via post-mortem examination of 39 young and 17 adult sheep. In $51.3 \%$ (20/39) of adolescents and in 100\% of adults, periodontal lesions were found at least at one tooth of the dental arch, with unilateral or bilateral periodontal lesions at the maxillary and mandibular teeth. Histopathological analysis of 13 sheep revealed pyogranulomatous inflammation. The second and third maxillary premolars were the teeth that were most affected in young animals, whereas the third pre-molar and the molars, of the maxilla and mandible, were most often affected in adults. These lesions led to severe bone destruction, alterations in the dental arch, occlusion, tooth loss and periodontal abscesses. The epidemiological and clinic-pathological characteristics of this periodontitis outbreak, described here for the first time in sheep in Brazil, were similar to those for bovine periodontitis ("cara inchada").
\end{abstract}

INDEX TERMS: Periodontal disease, periodontitis, epidemiology, sheep.

RESUMO.- [Aspectos epidemiológicos, clínicos e patológicos de um surto de periodontite em ovinos.] 0 trabalho teve por objetivo descrever os aspectos epidemiológi-

\footnotetext{
${ }^{1}$ Received on May 20, 2015.

Accepted for publication on July 20, 2016.

${ }^{2}$ Universidade Federal Rural da Amazônia, Campus Paragominas. Rodovia PA-256, Bairro Nova Conquista, Paragominas, PA 68627-451, Brazil. *Corresponding author: natalia.silva@ufra.edu.br

${ }^{3}$ Faculdade de Medicina Veterinária, Instituto de Medicina Veterinária, Campus de Castanhal, Universidade Federal do Pará (UFPA), Rodovia BR316 Km 61, Castanhal, PA 68741-740, Brazil. E-mail: diomedes@ufpa.br

${ }^{4}$ Departamento de Epidemiologia e Saúde Pública, Instituto de Veteriná-
}

cos e clínico-patológicos de um surto de periodontite em ovinos, ocorrido em uma propriedade rural em Benevides, no estado do Pará, Brasil. Os primeiros sinais clínicos da

ria (IV), Universidade Federal Rural do Rio de Janeiro ( UFRRJ), Seropédica, RJ 23890-000, Brazil. E-mail: marilene@ufrrj.br

${ }^{5}$ Programa de Pós-Graduação em Medicina Veterinária, Faculdade de Ciências Agrárias e Veterinárias, Universidade Estadual Paulista (Unesp), Via de Acesso Prof. Paulo Donato Castellane s/n, Jaboticabal, SP 14884900, Brazil. E-mail: carol_borsanelli@yahoo.com.br

${ }^{6}$ Departamento de Apoio, Produção e Saúde Animal, Faculdade de Medicina Veterinária de Araçatuba, Unesp, Campus de Araçatuba, Rua Clóvis Pestana 793, Jardim Dona Amélia, Araçatuba, SP 16050-680, Brazil. E-mail: isdutra@fmva.unesp.br 
presença da enfermidade no rebanho, visualizados como abaulamento nodular da mandíbula, foram observados aproximadamente um mês após a introdução dos animais em área de pastagem de Panicum maximum cv. Massai, que havia sido reformada recentemente, e suplementados com capim Elefante (Pennisetum purpureum). De 545 ovinos adultos, das raças Santa Inês, Dorper, Texel e seus mestiços, $20(3,7 \%)$ apresentaram abaulamento facial, predominantemente mandibular. Os 20 animais, na sua maioria com idades acima dos 36 meses, apresentavam baixo escore corporal, pelos arrepiados e sem brilho, alguns com afrouxamento e perda dos dentes pré-molares e molares inferiores e superiores, formação de abscesso e fístula, demonstrando dor à palpação e dificuldade na mastigação. No mesmo rebanho, a prevalência de lesões periodontais nos dentes pré-molares e molares foi avaliada por meio do exame post-mortem em 39 ovinos jovens e 17 adultos. Assim, 51,3\% (20/39) dos jovens e todos os adultos apresentavam lesões periodontais em pelo menos um dos dentes da arcada, com ocorrência uni ou bilateral nos maxilares e mandibulares. A análise histopatológica de 13 animais revelou processo inflamatório piogranulomatoso. Os dentes mais afetados nas arcadas dos animais jovens foram os segundo e terceiro pré-molares maxilares. Já nos adultos foram o terceiro pré-molar e os molares, tanto maxilares quanto mandibulares. As lesões causaram severa destruição óssea, alteração na arcada dentária, na oclusão, perda dental e ocorrência de abscessos periodontais. As características epidemiológicas e clínico-patológicas do surto de periodontite em ovinos, aqui descritos originalmente nesta espécie animal no País, assemelham-se às da periodontite bovina ("cara inchada").

TERMOS DE INDEXAÇÃO: Doença periodontal, periodontite, epidemiologia, ovinos.

\section{INTRODUCTION}

Periodontitis is an immuno-inflammatory response in a susceptible host that is caused by a complex microbiota, resulting in the loss of tissues that support the tooth, followed by its eventual exfoliation (Loesche 1993, Schenkein 2006). This disease can affect several species, including dogs (Peddle et al. 2009), cats (Booij-Vrieling et al. 2010), monkeys (Mikkelsen et al. 2008, Gaetti-Jardim et al. 2012) and humans (Susin \& Albandar 2005, Susin et al. 2005).

In the United Kingdom, Australia, New Zealand and other countries, ovine periodontitis is one of the main reasons for the premature culling of sheep (Ridler \& West 2007). Often referred to as "broken mouth", the natural course of periodontitis leads to tooth loosening and premature loss (Spence et al. 1988), and occurs predominantly in adult sheep, with some variability and seasonal prevalence; periodontitis contributes to weight loss, malnutrition and systemic health problems (Anderson \& Bulgin 1984, Baker \& Britt 1984).

In Brazil, periodontitis ("cara inchada") in ruminants has been described in cattle, and primarily affects calves during the stage of tooth eruption. This disease had great economic and health impact from the 1960s to the 1980s, and was initially associated with the introduction of cattle into large, newly formed pasture land in the Southeast, Midwest and North of Brazil (Döbereiner et al. 1974, 2000). Similarly, outbreaks were recorded following the renovation of pastures in areas that were previously endemic, with severe consequences to animal health (Dutra et al. 1993).

In the Northeast of the state of Pará, since 2009, dental problems in sheep have occasionally been observed by farmers and veterinarians on farms located in the municipalities of Bragança, Santo Antônio do Tauá, Castanhal, Paragominas and Benevides, and symptoms included mandible bulging, severe weight loss and death (Silva 2015). Therefore, the objective of this study was to describe the epidemiological, clinical and pathological aspects of an outbreak of periodontitis in sheep that occurred on a rural property in Benevides, Pará, Brazil.

\section{MATERIALS AND METHODS}

Information on the production system, particularly with respect to the renovation of pastures and fields for hay, the feeding and handling of sheep and disease outbreaks, was obtained from those responsible for the farm, which was located in the municipality of Benevides, Pará. Agricultural operations in these areas included plowing, disking, liming, fertilizing and planting of Panicum maximum cv. Massai grass throughconventional agricultural practices with the aid of soil analysis and professional consultation. The fields for hay, which were also renovated and provided roughage for the confined and semi-confined sheep, were stocked with elephant grass (Pennisetum purpureum). All animals were also fed mineral mixes intended for sheep, as well as brewery residues supplemented with sodium chloride solution, ad libitum.

Clinical examinations of 545 Santa Ines, Dorper, Texel, and crossbred sheep of the farm were performed according to the parameters described by Radostits et al. (2002) and Pugh (2004), with emphasis on extra-oral examinations. To perform age stratification analyses, sheep under one year of age were considered young, and those over one year were considered adult. Clinic and pathological signs were obtained during weekly visits to the farms between April and August of 2011. During the period, there were no mass treatment attempts to solve the issue.

From the sheep that were slaughtered for commercial reasons or that died during the follow-up period, macroscopic post mortem examinations of their heads were conducted to characterize any periodontal lesion (receding gums and periodontal pockets) at the premolar and molar teeth. The periodontal condition of 56 animals (39 young and 17 adult sheep) was evaluated.

The periodontal condition of the sheep was classified as normal when clinical examination revealed no change in marginal gingiva (gingiva accompanying the cementoenamel junction). Periodontal lesions were defined as the presence of periodontal pockets (not measured), sometimes accompanied by gingival recession, regardless of whether it was accompanied by food buildup or not. The lesions were classified as minor to severe based on gingival recession, furcation or root exposure, tooth mobility, bulging of the maxilla or mandible and periodontal abscess at any stage of its development. The present study evaluated only the condition of the premolars and molars; furthermore, tooth loss was ignored for the purpos of prevalence calculations.

In the 13 necropsied sheep, periodontal tissue fragments 
were collected and placed into $10 \%$ formalin and were routinely processed for histopathology and hematoxylin-eosin staining.

\section{RESULTS}

In the farm studied, sheep with mandibular bulging were observed about one month after being allowed to graze on pasture that had been recently renovated. While the adult sheep were kept in semi-confinement with access to $\mathrm{Pa}$ nicum maximum cv. Massai grass pasture and supplemented with elephant grass hay (Pennisetum purpureum), the young sheep remained confined and were fed roughage chopped from the hayfield. As the disease evolved naturally in the herd, the animals that first showed mandibular bulgimg were generally over 36 months of age, and they usually did not recover; although mandibular bulging stabilized in some animals, these sheep continued to perform poorly and completely lost body condition.

Using extra-oral clinical examinations, mandibular bulging was observed in $3.7 \%$ (20) of the 545 sheep (Fig.1). Affected animals generally showed different body scores based on evolution of the disease, including dull and ruffled coats, bulging of the submandibular and parotid lymph nodes, and loosening and loss of the premolars and upper and lower molars. In the more serious cases, we observed abscess formation and the presence of fistulas that drained purulent exudate. Some sheep exhibited signs of pain upon palpitation and difficulty chewing, as food was observed to drop from their mouths during feeding. In addition, newly lambed ewes with severe periodontal lesions involving a large number of teeth were unable to ruminate and entered a state of severe emaciation, often being unable to stand (Fig.2). Under these conditions, some sheep and their lambs died of starvation.

of the 39 dental arches from young sheep evaluated in the postmortem macroscopic examinations, $51.3 \%$ (20/39) had periodontal lesions (Fig.3 e 4), whereas all 17 dental arches from the adult animals showed lesions at

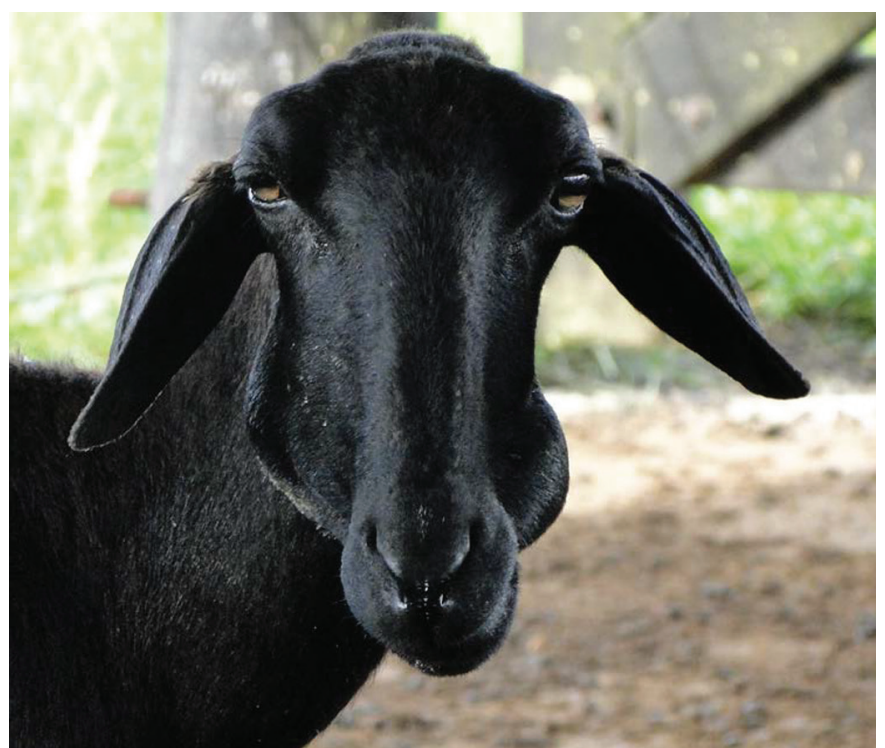

Fig.1. Sheep periodontitis: increased volume in the right mandibular body of an adult sheep. The enlargement observed in the left mandible resulted from food accumulation in the vestibule.

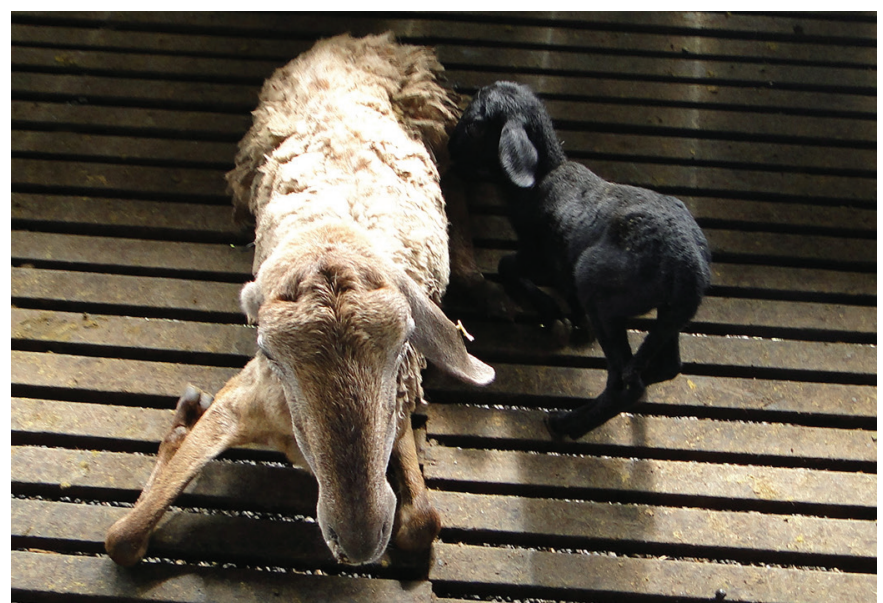

Fig.2. Sheep periodontitis: a newly lambed ewe exhibiting severe weakness and an inability to stand, and the lamb's attempt to suckle was unsuccessful.

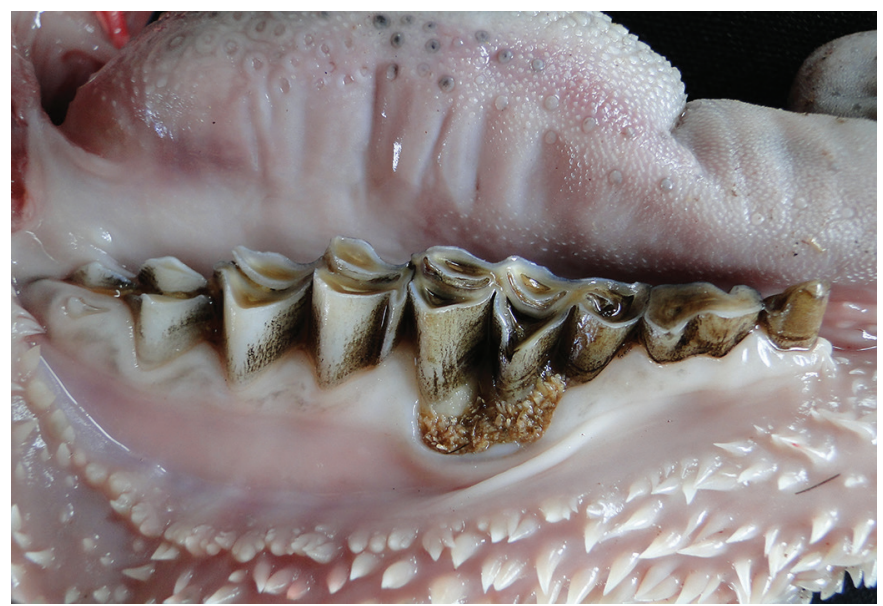

Fig.3. Sheep periodontitis: mandible of a young sheep from a post-mortem examination showing severe gingival recession with an accumulation of grass stalks in the third premolar (arrow) vestibular surface.

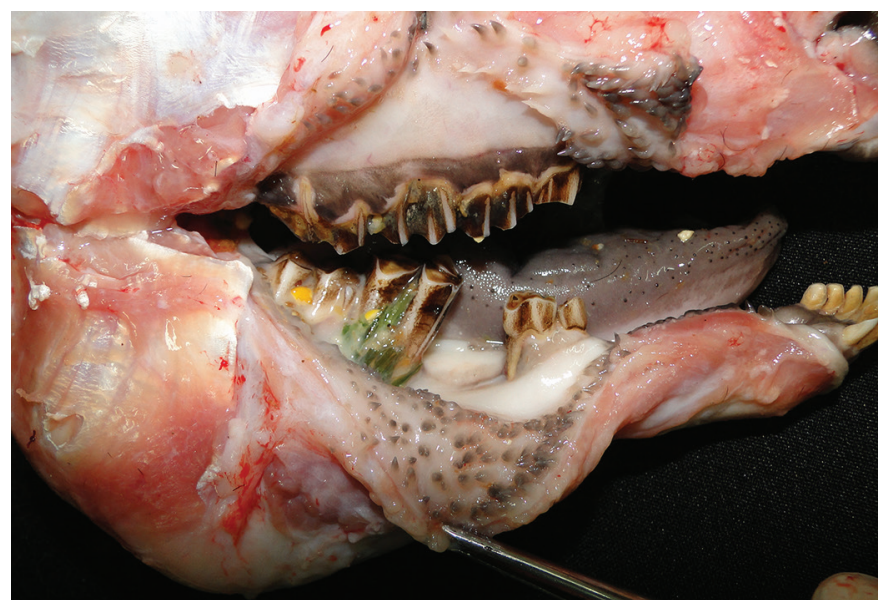

Fig.4. Sheep periodontitis: increased right mandibular body volume, loss of the third premolar and the presence of grass in the first molar observed in a post-mortem examination. 
Table 1. Distribution of periodontal lesions in young (39) and adult sheep (17) determined by postmortem examination of 56 animals that died of either natural causes or that were slaughtered during the disease outbreak in Benevides, Pará state, Brazil

\begin{tabular}{lccc}
\hline Tooth & \multicolumn{3}{c}{ Periodontal lesion n (\%) } \\
\cline { 2 - 4 } & Maxillary & Mandibular & Bilateral Lesion \\
\hline PM1 & $11(19.6 \%)$ & $2(3.6 \%)$ & $6(10.7 \%)$ \\
PM2 & $14(25.0 \%)$ & $4(7.1 \%)$ & $7(12.5 \%)$ \\
PM3 & $7(12.5 \%)$ & $3(5.4 \%)$ & $12(21.4 \%)$ \\
M1 & $2(3.6 \%)$ & $5(8.9 \%)$ & $13(23.2 \%)$ \\
M2 & $1(1.8 \%)$ & $10(17.9 \%)$ & $7(12.5 \%)$ \\
M3 & $5(8.9 \%)$ & $8(14.3 \%)$ & $3(5.4 \%)$
\end{tabular}

$\overline{\mathrm{PM}}=$ Pre-molar, $\mathrm{M}=$ Molar.

least at one pre-molar or molar tooth (or at both) of the mandible or maxilla, either uni- or bilaterally. The distribution of periodontal lesions among the 56 sheep examined postmortem is shown in Table 1 . Histopathological evaluation of periodontal tissues from 13 sheerp showed chronic inflammation characterized by fibroblast proliferation and the presence of lymphohistiocytic inflammatory cells, as well as suppurative processes characterized by pyogranulomatous inflammation.

\section{DISCUSSION}

This description of periodontitis in sheep, including specific epidemiological characteristics, clinical manifestations and pathological consequences, is the first of its kind in Brazilian scientific literature. However, the epidemiological and clinicopathological components associated with the outbreak observed by us were similar to those seen in bovine periodontitis ("cara inchada") as described by Döbereiner et al. (1974, 2000) and Dutra et al. (1993). Many of the symptoms described in this study, such as mandibular bulging, periodontal abscesses and the high prevalence of acute manifestations in adult sheep, are consistent with the natural history of periodontal diseases in other animal species, which are considered - just as they are in humans - multifactorial, polymicrobial infectious diseases which causal factors and modifiers are not fully known.

The first noticeable clinical manifestations of this disease in the herd were observed in adult sheep one month after grazing on newly renovated pastures and supplementation with elephant grass, cultivated with standard agricultural practices. According to Döbereiner et al. (1974) and Dutra et al. (1993), agricultural practices such as the formation and renovation of pastures or the new cultivation of forage in areas considered endemic can trigger outbreaks of bovine periodontitis. Environmental causal factors are thought to be associated with land management practices and animal diet, and when periodontitis is first introduced to a herd, its prevalence tends to be high but declines naturally over time, regardless of mineral supplementation (Döbereiner et al. 2004). Based on the historical information obtained at the time as well as the cross-sectional epidemiological nature of the study, it was not possible to obtain information on the occurrence of this disease in ruminants during previous years on this farm or in the surrounding region. Nevertheless, we cannot exclude the possibility that soil management and the use of roughage may have contributed to the onset of the disease, similar to what was described by Dutra et al. (1993) in severe outbreaks of periodontitis in calves in São Paulo state, Brazil. Evidence indicates that the increased number of actinomycetes in the disturbed soil and ingestion of sub-inhibitory concentrations of antibiotics, such as streptomycin and actinomycin, possibly be determinants of "swollen face" in cattle (Döbereiner et al. 2004).

The occurrence of mandibular bulging in $3.7 \%$ of the sheep certainly did not reflect the true extent of the periodontal status in the herd. According to Dutra \& Döbereiner (2007), in bovine periodontitis, when about $10 \%$ of animals show facial bulging, the prevalence of the disease can be as high as $60 \%$ in the herd as a whole, which they determined using intra-oral clinical examination as the diagnostic criteria. Using intra-oral clinical examinations, the actual status of periodontal disease in the herd can be established using objective criteria, although such procedures have practical limitations in the context of veterinary medicine for animal production. By contrast, macroscopic examinations of the dental arches of dead animals in the production system or of animals destined for slaughter have the potential to provide better information for assessing the presence and extent of periodontal disease in animal populations.

In the sheep examined initially, bulging was most commonly observed in the mandible, probably due to localized acute, and they were prone to apical migration and periodontal abscess formation. In young cattle with "cara inchada," there is a tendency towards uni- or bilateral bulging of the face as a result of chronic ossifying periostitis in the jaw bones, and the destruction of these bones often leads to bone remodeling and tumefaction of the face (Döbereiner et al. 1974). However, in periodontal infections in cattle as well as in the majority of sheep examined, abscesses did not tend to form but instead evolved as open alveolar infectious processes, often resulting in tooth exfoliation. The consequences to animal health manifested themselves differently depending on the number of teeth affected, the extent and progression of the lesions and pain, and the effects on chewing and rumination, as well as the duration of the process; severe cases culminated in the death of the animals due to their inability to feed themselves, particularly when they remained in endemic pastures or continued to eat the newly cultivated roughage.

Chronic periodontitis in sheep involving the premolars and molars, referred to as "broken mouth," often results in impaction of food in the periodontal pocket and halitosis, and is one of the primary causes of premature culling of sheep in the UK, New Zealand and Australia (Ridler \& West 2007). Those authors also reported, based on extensive literature dating back to the 1960 s, the same signs described in this study, including low body score, dull and ruffled coat, dysphagia, loosening and loss of premolars and upper and lower molars, and the formation of periodontal abscesses in the mandible and fistulas with purulent exudate drainage. We note that these periodontal abscesses appear to be a secondary complication of acute periodontitis. 
The prevalence of periodontal lesions determined through postmortem examination in $51.3 \%$ of the 39 sheep under one year of age and in all 17 of the adults revealed a situation of acute and chronic infection, beginning with the formation of a periodontal pocket and ultimately, reaching the gingiva, alveolar bone, cementum and periodontal ligament. Based on our criteria, periodontal lesions ranged from pouches with mild gingival retraction, often located in the interdental papilla, to severe changes resulting in significant clinical loss of attachment; no surveys or other means of diagnosis were used that would allow for a more precise clinical evaluation of these processes. However, despite these somewhat arbitrary criteria based on visual inspection, it was clear that clinical damage was present and its extent was described, and health and welfare of the sheep was certainly affected.

Although the young sheep did not have access to the renovated pastures, they were fed elephant grass cut from renovated areas, and their dams still had access to these pastures, which may have contributed to the occurrence of the disease among the young animals. One interesting observation by Döbereiner et al. (1987) was that milk from the dam's udder contributed to the occurrence of periodontitis in calves when the cows had access to recently formed pasture, even when calves were fed forage from an area considered free of the disease. Furthermore, it is worth noting that the factors that increase or decrease the prevalence of periodontitis in sheep in different categories of animals, or even between individuals of the same age, remain unknown. For example, in the epidemiology of periodontal diseases in humans, the higher prevalence of these conditions in adults is more likely due to longer exposure times to risk factors and is not related to age (Papapanou et al. 1991).

Periodontal lesions were common in chewing teeth (Table 1), similar to those described in bovine (Döbereiner et al. 1974) and ovine periodontitis (Spence \& Aitchison 1986), often resulting in severe clinical loss of tooth attachment, which certainly negatively affected animal production and welfare. Although it was not a specific objective of this study to evaluate indicators of such parameters, it can be concluded that the occurrence of periodontitis and the clinical manifestations resulting from difficulty in chewing and ruminating can be associated with a low body condition score in the affected animals. The economic consequences of periodontitis in sheep production can be quite considerable, and a study of this disease in Australia, New Zealand and the UK evaluated significant losses due to low feed conversion, decreased reproductive life of the animals, increased cost due to replacement and loss of market value of animals (Ridler \& West 2007).

\section{CONCLUSIONS}

An outbreak of ovine periodontitis resulted in a range of symptoms of varying severity, including clinical loss of attachment for pre-molar and molar teeth, detrimental effects on mastication and loss of body conditioning, which occurred despite adequate soil management practices and feeding with good quality forage, resulting in serious effects on animal health and production.
The epidemiological, clinical and pathological profiles of ovine periodontitis were similar to those observed in bovine periodontitis, although there were some distinct differences, as ovine periodontitis primarily affects adult animals and manifests itself with a low prevalence of mandibular bulging and periodontal abscess formation in the herd.

Acknowledgments.- The authors would like to thank the Pró-Reitoria de Pesquisa e Pós Graduação da Universidade Federal do Pará (Propesp-UFPA) for their financial support.

Conflict of interest.- The authors have no conflict of interest to declare.

\section{REFERENCES}

Anderson B.C. \& Bulgin M.S. 1984. Starvation associated with dental disease in range ewes. J. Am. Vet. Med. Assoc. 184(6):737-738.

Baker J.R. \& Britt D.P. 1984. Dental calculus and periodontal disease in sheep. Vet. Rec. 115(16):411-412.

Booij-Vrieling H.E., van der Reijden W.A., Houwers D.J., De Wit W.E., Bosch-Tijhof C.J., Penning L.C., Van Winkelhoff A.J. \& Hazewinkel H.A. 2010. Comparison of periodontal pathogens between cats and their owners. Vet. Microbiol. 144(1/2):147-152.

Döbereiner J., Inada T. \& Tokarnia C.H. 1974. “Cara inchada”, doença peridentária em bovinos. Pesq. Agropec. Bras. 9(7):63-85.

Döbereiner J., Rosa I.V. \& Lazzari A.A. 1987. Efeito do leite materno sobre as lesões peridentárias da "cara inchada" em bezerros. Pesq. Vet. Bras. 7(3):97-99.

Döbereiner J., Dutra I.S., Rosa I.V. \& Blobel H. 2000. “Cara inchada” of cattle, an infectious, apparently soil antibiotics-dependent periodontitis in Brazil. Pesq. Vet. Bras. 20(2):47-64.

Döbereiner J., Dutra I.S. \& Rosa I.V. 2004. A etiologia da "cara inchada", uma periodontite enzoótica dos bovinos. Pesq. Vet. Bras. 24(1):50-56.

Dutra I.S. \& Döbereiner J. 2007. Cara inchada dos bovinos, p.485-490. In: Riet-Correa F., Schild A.L., Lemos R.A.A. \& Borges J.R.J. (Eds), Doenças de Ruminantes e Equídeos. Vol.1. 3a ed. Pallotti, Santa Maria, RS.

Dutra I.S., Matsumoto T. \& Döbereiner J. 1993. Surtos de periodontite em bezerros ("cara inchada") associados ao manejo do solo. Pes. Vet. Bras. 13(1/2):1-4.

Gaetti-Jardim Jr E., Monti L.M., Ciesielski F.I.N., Gaetti-Jardim E.C., Okamoto A.C., Schweitzer C.M. \& Avila-Campos M.J. 2012. Subgingival microbiota from Cebus apella (capuchin monkey) with different periodontal conditions. Anaerobe 18:263-269.

Loesche W.J. 1993. Bacterial mediator in periodontal diseases. Clin. Infect. Dis. 16(Supl.4):S203-S210.

Mikkelsen D., Milinovich G.J., Burrell P.C., Huynh S.C., Pettett L.M., Blackall L.L., Trott D.J. \& Bird P.S. 2008. Phylogenetic analysis of Porphyromonas species isolated from the oral cavity of Australian marsupials. Environ. Microbiol. 10(9):2425-2432.

Papapanou P. N., Lindhe J., Sterret J.D. \& Eneroth L. 1991. Considerations on the contribution of geing to loss of periodontal tissue support. J. Clin. Periodontol. 18(8):611-615.

Peddle G.D., Drobatz K.J., Harvey C.E., Adams A. \& Sleeper M.M. 2009. Association of periodontal disease, oral procedures, and other clinical findings with bacterial endocarditis in dogs. J. Am. Vet. Med. Assoc. 234(1):100-107.

Pugh D.G. 2004. Clínica de Ovinos e Caprinos. Roca, São Paulo, SP. 528p.

Radostits O.M., Gay C.C., Blood D.C. \& Hinchcliff K.W. 2002. Clínica Veterinária: um tratado de doenças dos bovinos, ovinos, suínos, caprinos e equinos. 9a ed. Guanabara Koogan, Rio de Janeiro, RJ. 1770p.

Ridler A.L. \& West D.M. 2007. Diseases of the oral cavity, p.165-171. In: Aitken I.D. (Ed.), Diseases of Sheep. 4th ed. Blackwell Publishing, Oxford, UK.

Schenkein H.A. 2006. Host responses in maintaining periodontal health and determining periodontal disease. Periodontology 2000 40:77-93. 
Silva N.S. 2015. Periodontite em ovinos no estado do Pará: etiologia, aspectos epidemiológicos e clínico-patológicos. Tese de Doutorado em Ciência Animal, Universidade Federal do Pará, Belém, PA. 104p.

Spence J. \& Aitchison G. 1986. Clinical aspects of dental disease in sheep. In Practice 8(4):128-135.

Spence J.A., Aitchinson G.U. \& Fraser J. 1988. Development of periodontal disease in a single flock of sheep: clinical signs, morphology of subgingival plaque and influence of antimicrobial agents. Res. Vet. Sci. 45(3):324-331.

Susin C. \& Albandar J.M. 2005. Aggressive periodontitis in an urban population in southern Brazil. J. Periodontol. 76(3):468-475.

Susin C., Valle P., Oppermann R.V., Haugejorden O. \& Albandar J.M. 2005. Occurrence and risk indicators of increased probing depth in an adult Brazilian population. J. Clin. Periodont. 32(2):123-129. 